\title{
BEHAVIOUR OF POTASSIUM DESORPTION INDICATOR IN SOME SEMICTITIC RICH SOILS AT NORTHERN OF IRAQ
}

Mohammed Tahir Said Khalil

College of Agriculture and Forestry, Mosul University, Iraq.

E-mail: dr_mohammed1951@yahoo.com

\begin{abstract}
A laboratory study was conducted to determine potassium adsorption and desorption indicators for 12 semictitic rich soils in Dohuk governorate northern of Iraq. Potassium adsorption isotherms was constructed by using miscible displacement technique with $0.01 \mathrm{M} \mathrm{KCl}$ in $2.5 \mathrm{gm} \mathrm{Ca}^{2+}$ saturated soil for 60 minute with 10 minutes interval at a rate flow $1 \mathrm{ml}$ per minute. After that soil samples were redisplaced with $\mathrm{Ca}^{2+}$ by using $0.01 \mathrm{M} \mathrm{CaCl}_{2}$ in the same method. The results showed an average amount of $\mathrm{K}^{+}$adsorbed ranged from 13.59 - 32.1 c.mole. $\mathrm{kg}^{-1}$, while average amount of $\mathrm{K}^{+}$desorbed ranged from $(0.53-4.45)$ c.mole. $\mathrm{kg}^{-1}$ and hence soil samples had a high hysteresis ranged from $70.3 \%$ to $96 \%$ and low desorption index ranged between $0.01-0.27$.

Key words: semictite, adsorption, hysteresis, desorption index.
\end{abstract}

Received: 8/1/2012 Accepted: 21/5/2012

\section{INTRODUCTION}

Potassium is an essential nutritive element for all plants (Mengel et al., 2001, White, 2003) and its availability in soils is limited by texture, clay minerals, rate of Fertilization, moisture content (Samadi, 2006, Simonsson, et al., 2007) and fertilizer management (Krauss, 2003). Rate of $\mathrm{K}^{+}$adsorption after fertilizer addition differs among soils because the response of crops to applied potassium are earlier and thus its unpredictability is due to different adsorption characteristics of potassium by various soils . Depending upon amount and type of clay minerals, up to $57 \%$ of the applied potassium can be adsorbed by soil colloids (Shanwall and Dahiya, 2006), Amount of $\mathrm{K}^{+}$adsorbed on clay particles depends on kinetic and thermodynamic factors (Du, 2004). Soils with high potassium specificity like illite and vermiculite rich soils (Karabachsch and Ultrich, 2007). Similarly, the rate of $\mathrm{K}^{+}$adsorption on illite and vermiculite was reported to be much slower than montmorillonite and kaolinite (Jalali, 2007, Al-Azawi, 2010). Clay minerals like semictite and kaolinite easily release all of their $\mathrm{K}^{+}$adsorbed than illite and vermiculite (Ghosh and Sing, 2001), upon removal rate by plants and rapidity at which potassium can be desorbed from the adsorbed phase whereas initial adsorption equilibrium solution levels serves as an index of potassium release (Rao et al., 2004, Jalali, 2006) . This equilibrium of potassium concentration appears to provide a better index of soil fertility. Desorption index refers to soil ability to release potassium after its addition to soil. A knowledge about the variation in $\mathrm{K}^{+}$adsorption among soils and equilibrium between solid-liquid phases of $\mathrm{K}^{+}$are necessary to predict desorption index of added $\mathrm{K}^{+}$fertilizers in soils to make precise $\mathrm{K}^{+}$fertilizers recommendations (Shanwall, 2006, Poonia, 2007, Rao and Taker, 2007). So a little is known available to $\mathrm{K}^{+}$adsorption-desorption in Iraqi soils. Study aimed to determine the effect of elapsed time on $\mathrm{K}^{+}$adsorption-desorption characteristics and desorption index of studied soils. 


\section{MATEIALS AND METHODS}

Twelve soils were sampled within Vertisols order in Dohuk Governorate at northern Iraq. Soil samples were air-dried and grounded to pass through $2 \mathrm{~mm}$ sieve. Some chemical and physical properties are determined according the methods described by Carter and Gregorich, (2008) table.1,2. Soils were classified according to (Anonymous, 2006). Potassium adsorption was carried out by using miscible displacement technique as mentioned by Cracksi and Sparks, (1985), Shanwall. (2006) can be summarized as follows:

Calcium saturation: 2.5 gm of soil samples were placed into $47 \mathrm{~mm}$ Nucleopore filtered-column. The samples were saturated with $0.1 \mathrm{M} \mathrm{CaCl} \mathrm{Cl}_{2}$ solution at rate of 1 ml.min ${ }^{-1}$ until equilibrium was reached later on (to remove $K_{e x}$ from the soil sample).

$\mathrm{K}^{+}$adsorption: $\mathrm{Ca}^{2+}$ saturated soil was leached by using $0.01 \mathrm{M} \mathrm{KCl}$ solution supplied at steady rate to renew the soil solution and to assess $\mathrm{K}^{+}$adsorption at constant $\mathrm{K}^{+}$concentration in soil solution. Solution was leached at the rate of $1 \mathrm{ml} . \mathrm{min}^{-1}$ for each 10 minutes. Difference between initial and final $\mathrm{K}^{+}$represented the adsorbed by the soil.

$\mathrm{K}^{+}$desorption: $\mathrm{K}^{+}$desorption was initiated by using $0.01 \mathrm{M} \mathrm{CaCl}_{2}$ solution which passed through soil at rate $1 \mathrm{ml} \cdot \mathrm{min}^{-1}$ for a period ranged from 10 to 60 minutes. Quantity of $\mathrm{K}^{+}$in solution for both adsorption and desorption was measured by flame photometer.

Table (1): Some physical and chemical properties for studied soils.

\begin{tabular}{|c|c|c|c|c|c|c|c|c|c|c|}
\hline \multirow[t]{3}{*}{ Location } & \multirow[t]{3}{*}{ No. } & \multirow[t]{2}{*}{ Sand } & \multirow[t]{2}{*}{ Silt } & \multirow[t]{2}{*}{ Clay } & \multirow{2}{*}{$\begin{array}{c}\text { Organic. } \\
\text { matter }\end{array}$} & \multicolumn{2}{|c|}{$\mathrm{CaCO}_{3}$} & \multirow{3}{*}{$\begin{array}{c}\text { CEC } \\
\text { c.mole. } \\
\mathrm{kg}^{-1}\end{array}$} & \multirow[t]{3}{*}{$\mathrm{pH}$} & \multirow{3}{*}{$\begin{array}{c}\mathrm{EC} \\
\mathrm{dS} \cdot \mathrm{m}^{-1}\end{array}$} \\
\hline & & & & & & total & active & & & \\
\hline & & \multicolumn{6}{|c|}{ gm. $\mathrm{kg}^{-1}$} & & & \\
\hline \multirow{4}{*}{ Someel } & 1 & 140 & 380 & 480 & 13 & 115 & 45 & 41.2 & 7.9 & 0.5 \\
\hline & 2 & 130 & 415 & 455 & 20 & 165 & 45 & 37 & 7.8 & 0.5 \\
\hline & 3 & 025 & 480 & 495 & 12 & 173 & 65 & 25 & 7.7 & 0.4 \\
\hline & 4 & 120 & 490 & 390 & 14 & 182 & 91 & 20 & 7.8 & 0.5 \\
\hline \multirow{4}{*}{ Bateel } & 5 & 075 & 510 & 415 & 16 & 221 & 52 & 26 & 7.9 & 0.3 \\
\hline & 6 & 125 & 515 & 360 & 15 & 291 & 65 & 30.2 & 7.7 & 0.6 \\
\hline & 7 & 120 & 500 & 380 & 12 & 282 & 45 & 29.1 & 7.8 & 0.6 \\
\hline & 8 & 110 & 550 & 310 & 12 & 261 & 55 & 30.8 & 7.6 & 0.8 \\
\hline \multirow{4}{*}{ Zakho } & 9 & 200 & 440 & 360 & 21 & 225 & 60 & 28 & 8.0 & 0.3 \\
\hline & 10 & 180 & 470 & 350 & 13 & 196 & 65 & 24.4 & 7.6 & 0.3 \\
\hline & 11 & 140 & 450 & 410 & 14 & 231 & 54 & 28.5 & 8.1 & 0.4 \\
\hline & 12 & 220 & 400 & 380 & 15 & 230 & 51 & 28.9 & 7.9 & 0.4 \\
\hline
\end{tabular}

$$
\begin{aligned}
\% \mathrm{~K}^{+} \text {desorbed }= & \frac{\mathrm{K}^{+} \text {desorbed }}{-\mathrm{K}^{+} \text {adsorbed }} \times 100 \\
& \mathrm{~K}^{+} \text {adsorbed }-\mathrm{K}^{+} \text {desorbed }
\end{aligned}
$$

Desorption indicator: According to (Marzadori, 1991), the desorption index was 
Mesopotamia J. of Agric.

Vol.(41) No.(4 ) 2013
ISSN:2224-9796(Online)

ISSN:1815-316X(Print)

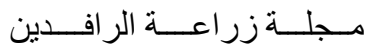

المجلد (41) العدد (4) 2013 العافين

calculated by the following formula :

$\mathrm{DI}=\mathrm{md} / \mathrm{ma} \times 100$

Where DI: desorption Indicator.

md: desorption isotherm slope.

ma: adsorption isotherm slope.

Table (2): Clay mineralogy and various $\mathrm{K}^{+}$forms for studied soils.

\begin{tabular}{|c|c|c|c|c|c|c|c|}
\hline \multirow{2}{*}{ No } & \multicolumn{4}{|c|}{ \% Clay minerals } & \multicolumn{3}{|c|}{$\mathrm{K}^{+}$} \\
\cline { 2 - 8 } & Illite & Semictite & Vermiculite & Kaolinite & \multicolumn{3}{|c|}{ c.mole.kg } \\
\hline 1 & 20 & 19 & 13 & 20 & 0.011 & 0.75 & 1.29 \\
\hline 2 & 30 & 31 & 5 & 21 & 0.005 & 0.73 & 1.16 \\
\hline 3 & 33 & 27 & 12 & 26 & 0.003 & 0.49 & 0.91 \\
\hline 4 & 29 & 20 & 17 & 32 & 0.010 & 0.93 & 3.46 \\
\hline 5 & 22 & 30 & 10 & 22 & 0.003 & 0.53 & 2.06 \\
\hline 6 & 22 & 21 & 14 & 29 & 0.004 & 0.51 & 0.96 \\
\hline 7 & 27 & 18 & 21 & 21 & 0.011 & 0.73 & 1.47 \\
\hline 8 & 38 & 17 & 13 & 19 & 0.007 & 0.57 & 1.34 \\
\hline 9 & 30 & 31 & 15 & 22 & 0.003 & 0.48 & 0.74 \\
\hline 10 & 14 & 22 & 19 & 21 & 0.011 & 0.54 & 0.91 \\
\hline 11 & 19 & 25 & 14 & 19 & 0.016 & 0.4 & 0.61 \\
\hline 12 & 21 & 20 & 11 & 22 & 0.005 & 0.31 & 0.28 \\
\hline
\end{tabular}

\section{RESULTS AND DISCUSSIONS}

Adsorption capacity: Table. 3 indicates the adsorption capacity (AC) of the studied soils, values of $\mathrm{AC}$ were ranged from 13.9 c.mole. $\mathrm{kg}^{-1}$ (sample No.3) to 32.1 c.mole. $\mathrm{kg}^{-1}$ (sample No.7). This variation in $\mathrm{K}^{+}$adsorption among studied soils reflects the differences in chemical mineralogical properties of the studied soils, as a result of X-ray diffraction. The smectite is dominant mineral in soil samples, it could increase $\mathrm{K}^{+}$fixation. In general smectite is considered to have the highest adsorption capacity, but chlorite have low capacity. The adsorption curve Fig.1 is initially showed that $\mathrm{K}^{+}$adsorption was rapid and then it leveled off with time. The initial fast adsorption may be related to the $\mathrm{K}^{+}$adsorption on the surface sites. Similar result was found by Mam Rasul and Al-Obaidi (2010) .

Desorption capacity: The data in table. 3 indicated that the soil desorption capacity ranged from 0.53 c.mole. $\mathrm{kg}^{-1}$ (sample No.3) to 4.45 c.mole. $\mathrm{kg}^{-1}$ (sample No.10). The maximum quantity of $\mathrm{K}^{+}$desorption was related to silt fraction in soil. Positive correlation between $\mathrm{K}^{+}$desorption and silt fraction was recorded $\left(r=0.68^{*}\right)$. Similar results was observed by Simard et al.,(1992) found that $\mathrm{K}^{+}$released rate from clay and silt was larger than sand to soil mineral structure Badraoui et al., (1992), they found that the soil content mica, illite and vermiculate minerals have a high release rate of $\mathrm{K}^{+}$compared with kaolinite minerals.

Hysteresis of potassium: Strong hysteresis behavior of $\mathrm{K}^{+}$adsorption-desorption was observed for studied soils as illustrated by discrepancy between adsorption and 
Mesopotamia J. of Agric.

Vol.(41) No.(4 ) 2013
ISSN:2224-9796(Online)

ISSN:1815-316X(Print)

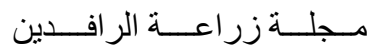

المجلد (41) العدد (4) 2013 العاعن

desorption isotherm Fig.1. Due to strong adsorption and low recovery, results indicated that potassium is not susceptible to leaching losses from the surface sites. Low values of DI increases in hysteresis. Table 3 showed the lower DI value which indicates an increase in difficulty of the $\mathrm{K}^{+}$adsorbed to $\mathrm{K}^{+}$-desorbed from soil surfaces. Highest value of $\mathrm{K}^{+}$hysteresis $96 \%$ was recorded from (sample No.10), lower value $70.3 \%$ were obtained from (samples No.3) tab.3 and fig1. Little amount of $\mathrm{K}^{+}$adsorption was desorbed back into the liquid phase indicating to
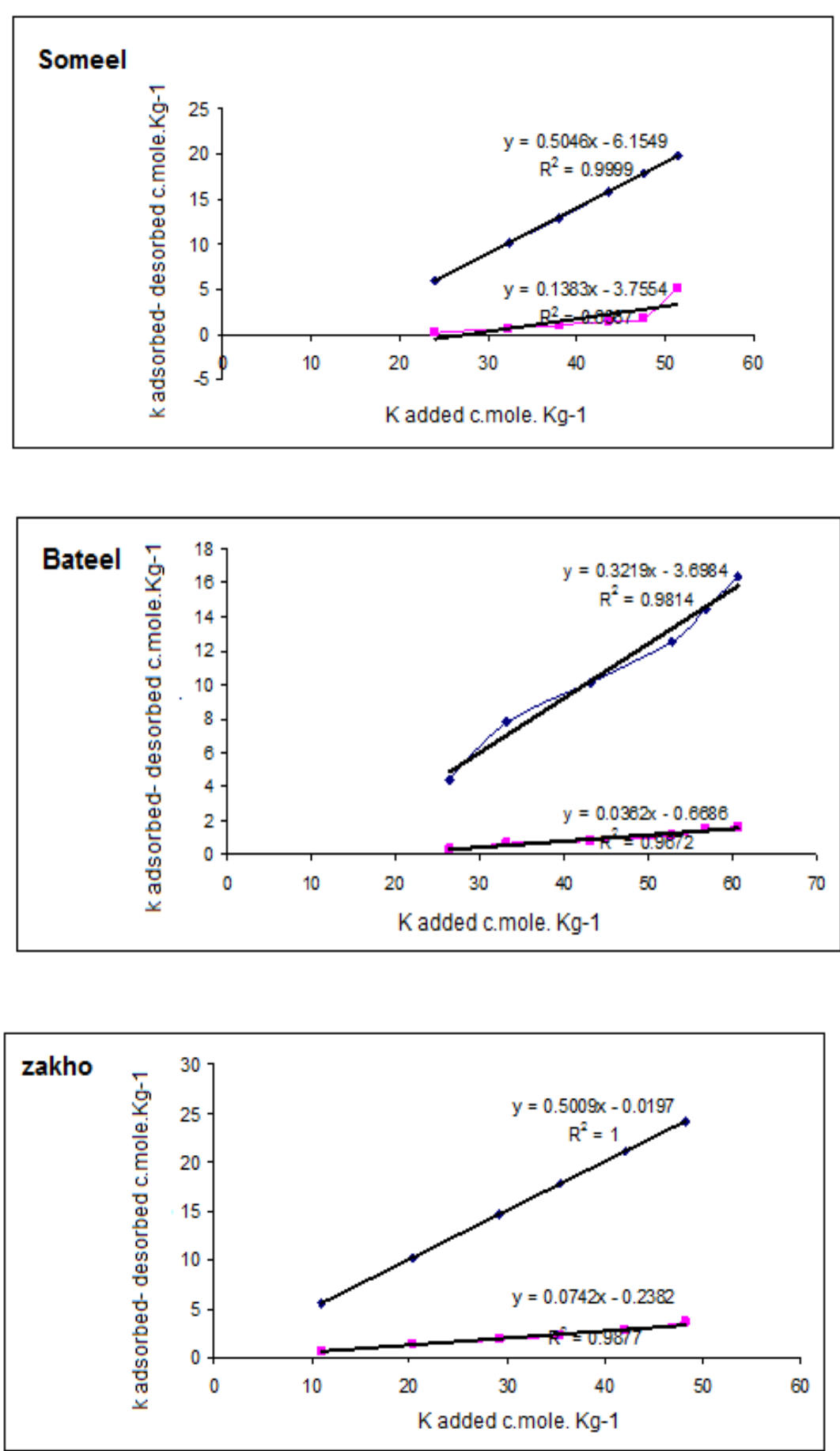

Fig. (1): Regression relationship between $\mathrm{K}^{+}$added and $\mathrm{K}^{+}$adsorbed-desorbed for studied soils. 
Mesopotamia J. of Agric.

Vol.(41) No.(4 ) 2013
ISSN:2224-9796(Online)

ISSN:1815-316X(Print)

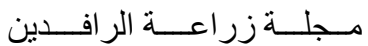

المجلد (41) العدد (4) 2013

Table (3) : $\mathrm{K}^{+}$adsorption-desorption, \% $\mathrm{K}$ adsorbed, \% $\mathrm{K}$ hysteresis and desorption index for studied soils.

\begin{tabular}{|c|c|c|c|c|c|c|}
\hline \multirow{2}{*}{ No. } & $\mathrm{K}^{+}$adsorbed & $\mathrm{K}^{+}$desorbed & \multirow{2}{*}{$\mathrm{K}^{+}$} & \multicolumn{2}{|c|}{$\% \mathrm{~K}^{+}$} & desorption \\
& \multicolumn{2}{|c}{ c.mole. $\mathrm{Kg}^{-1}$} & hysteresis & desorbed & hysteresis & Index (DI) \\
\hline 1 & 19.8 & 2.17 & 17.63 & 11.0 & $89.0 \%$ & 0.27 \\
\hline 2 & 14.8 & 0.94 & 13.86 & 6.4 & $93.6 \%$ & 0.01 \\
\hline 3 & 13.9 & 0.53 & 13.37 & 3.9 & $96.0 \%$ & 0.50 \\
\hline 4 & 15.1 & 1.68 & 13.42 & 11.1 & $88.8 \%$ & 0.13 \\
\hline 5 & 16.4 & 1.65 & 14.75 & 10.0 & $89.9 \%$ & 0.11 \\
\hline 6 & 17.3 & 2.09 & 15.21 & 11.8 & $87.9 \%$ & 0.20 \\
\hline 7 & 32.1 & 3.01 & 20.09 & 9.4 & $90.6 \%$ & 0.10 \\
\hline 8 & 29.7 & 4.07 & 25.63 & 13.7 & $86.3 \%$ & 0.15 \\
\hline 9 & 29.2 & 3.52 & 20.68 & 14.5 & $85.5 \%$ & 0.15 \\
\hline 10 & 16.0 & 4.45 & 11.55 & 15.3 & $70.3 \%$ & 0.02 \\
\hline 11 & 17.0 & 1.46 & 15.54 & 8.6 & $91.4 \%$ & 0.11 \\
\hline 12 & 23.7 & 3.89 & 19.81 & 16.4 & $83.6 \%$ & 0.18 \\
\hline
\end{tabular}

strong tendency of $\mathrm{K}^{+}$to be sorbed by clay or organic matter Fig.1, thereby these soils have a large specific surface area to sorbed. These results agree with those of Huang (2005), Khodabaksh (2006), Karabachsh and Ultrich (2007), Al-Semmak (2008), Al-Obaidi and Hussain (2010) who referred that rich semictitic and illitic soils of northern Iraq (Nineveh, Duhok, Erbil, Sulaimania governorates), have a high fixing capacity for potassium.

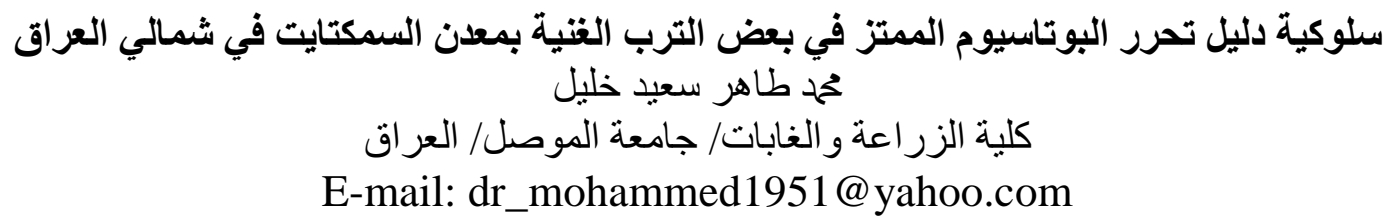

E-mail:dr_mohammed1951@yahoo.com

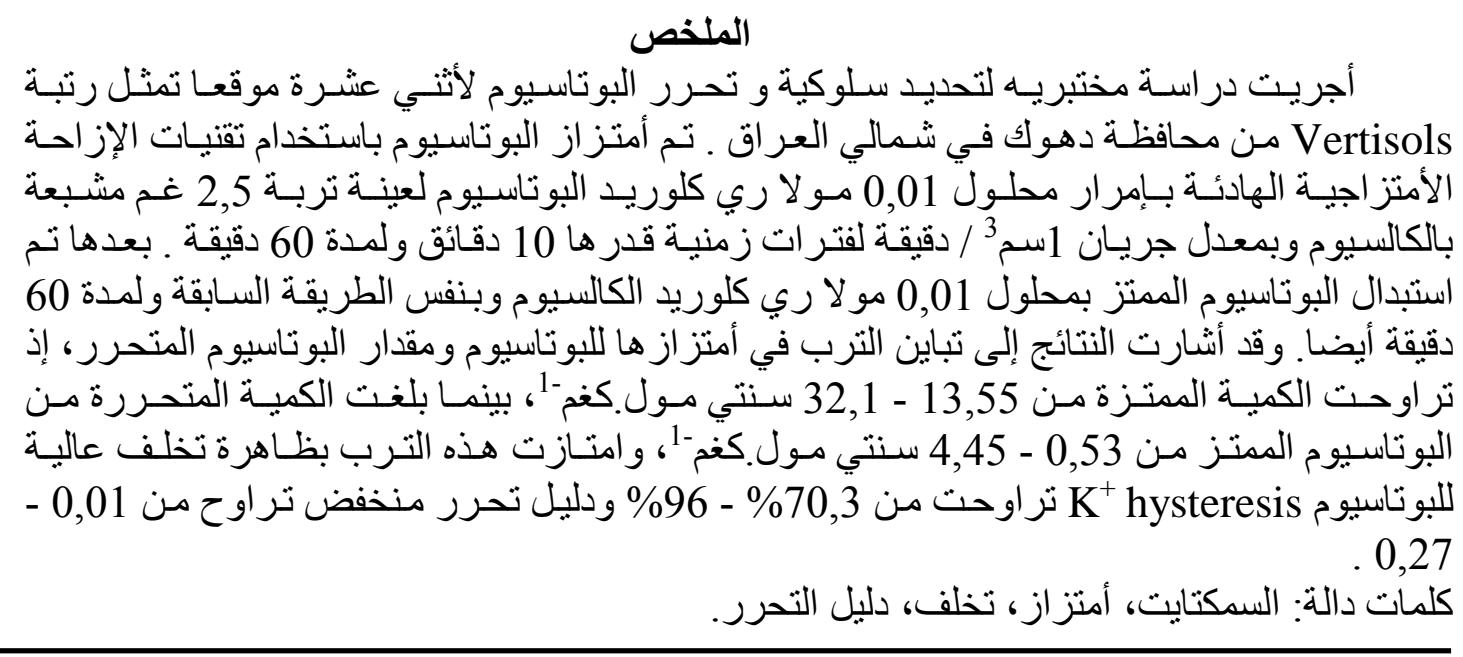

تاريخ تسلم البحث: 2012/1/8 وقبوله: 2012/5/21

\section{REFERENCES}

Al-Azawi, H. A. (2010). Effect of Cation Exchange Capacity on Availability of Potassium to the Maize Crop In a Heavy Clay Soil. M.Sc. Thesis. 
Mesopotamia J. of Agric.

Vol.(41) No.(4 ) 2013
ISSN:2224-9796(Online)

ISSN:1815-316X(Print)
المجلد (41) العدد (4) اعــة الر افــدين 2013

Agronomy and Soil Science School of Environment and Rural Science. University of New England.

Al-Obaidi, M. A. and A. R. Hussain (2010). Kinetics of potassium adsorption and desorption in some Nineveh Governorate soils. Mesopotamia Agricultural Journal, 38(4): 2010.

Anonymous, (2008). Key To Soil Taxonomy. Soil Survey Staff, $10^{\text {th }}$ edition. USDA, NRCS. USA.

Al- Semmak, Q and H, Abaas (2008). The Behavior Of Some Potassium Fertilizers In Cultivated Desert Soil Under Different Irrigation Systems. PhD Thesis Submitted to College of Agriculture, University of Baghdad, Iraq.

Badraoui, M. M. ; M. Agbani ; P. R. Bloom ; R. Bouabid ; B. Soudi ; A. Mimouni and S. Bouchara (1992). Chemistry and Mineralogy of Potassium. Morocco Int. Centre of Agricultural Researches In Dry Areas. ICARDA.

Carter, M. R. and E. G. Gregorich (2008). Soil Sampling and Methods of Analysis. $2^{\text {nd }}$ edition. Canadian Society of Soil Science. Canada.

Cracksi, T. H. and D. L. Sparks (1985). A modified miscible displacement technique for investigating adsorption-desorption kinetics in Soils. Soil Science Society Journal. 49:1114-1116.

Du, Y. J. (2004). Some factors controlling the adsorption of potassium ions on clay soils. Applied Clay Sciences. 27: 209 - 213.

Ghosh, B. N. and R. D. Sing (2001). Potassium release characteristics for some soils of Uttar Pradesh hills varying in altitude and their clay mineralogy.Geoderma. 104: 134 - 144.

Huang, M. (2005). Chemistry Of Potassium In Soil. American Society of Soil Sciences. WI. p 227 - 292.

Jalali, M. (2006). Site-Specific Potassium Application Based On The Fertilizer Potassium Availability Index Of Soil. Precision Agric. Springer Science Business Media, LL.C.

Karabachsch, M, and B. Ulrich (2007). Kalium - dynamic and kalium - fixiegrung, Nord westicaischer Boden. Zeitschrift Für $P$ flanzenernahrungund Bodenkunde, 141(5): 535 - 546.

Khodabaksh, P. K. (2006). Sorption - desorption behavior of phosphorous and potassium in four series of Isfahan - $18^{\text {th }}$ World Congress of Soil Science. July 9 - 15, 2005. Philadelphia, Pennsylvania, USA 154 - 159.

Krauss, A. (2003). Assessing soil potassium in view of contemporary crop production. Regional. IPI. LTA-LUA. Workshop on Balanced Fertilization In Contemporary Plant Production IPI.

Mam Rasul, G. A. and M. A. Al-Obaidi (2010). Kinetics of potassium desorption from entisols, vertisols and mollisols using modified miscible displacement technique in Sulaimania Governorate. Mesopotamia Journal of Agriculture, 39(3): 32 - 38.

Mangel, K.; E. A. Kirkby; H. Kosegarten and T. Appel (2001). Principles of Plant Nutrition, $5^{\text {th }}$ ed. Kluwer. Academic Publishers, Dordrecht, Netherland.

Marzadori, C. ; A.I. Vittori ; C. Ciavatta and P. Sequi (1991). Soil Organic matter influence on adsorption and desorption of boron, Soil Science Society of American Journal, 55: 1582- 1585. 
Poonia, S. R. and E. A. Nicderbudde (2007). Exchange equilibrium of potassium in soils. $\amalg-$ Effect of $\mathrm{K}+$ fertilization on $\mathrm{K}^{+}-\mathrm{Ca}^{2+}$ exchange. Journal of Plant Nutrition and Soil Science. 149(0): 691 - 701.

Rao, Ch. S.; A. Swarup ; A. S. Rao and U. R. Gobal (2004). Kinetics of nonexchangeable potassium release from rapaquept as influenced by long term cropping fertilization and manuring. Australian journal of Soil Researches, 37(7): 317 - 328.

Rao, Ch. S. and P. N. Taker (2007). Potassium status in maize rhizosphere soils. Zeitschrift Für Pflanzenernabrung and Bodenkunde, 16(1): 103 - 106.

Samadi, A. (2006). Potassium exchange in therms as a plant availability index in selected calcareous soils of western Azarbaijan Province, Iranean, Turkish Journal Of Agriculture, 30: 213 - 222.

Shanwall, A. V. (2006). Characterization of soil potassium derived from sorption desorption experiments. Plant and Soil, 251(2): 331 - 341.

Shanwall, A. V. and S. S. Dahiya (2006). Potassium Dynamics and Mineralogy Encyclopedia of Soil Science. $2^{\text {nd }}$ edition . In lal (ed.).

Simard, R. R.; G. R. Dekimpe and J. Zizka (1992). Release of potassium and magnesium from soil fraction and its kinetics, Soil Science Society of American Journal, 55: 1421 - 1429.

Simonsson, M.; S. Anderson; Y. Angrich - Ranget; S. Hillier; L. Mattsson and I. Oborn (2007). Potassium release and fixation as function of fertilizer application rate and soil parent material. Geoderma 140: 188 - 198.

White, J. (2003). Potassium nutrition in Australian high yielding maize product system - review - paper presented at $5^{\text {th }}$ Australian Maize Conference 16 $20^{\text {th }}$ February 2003. Toowoomba Queensland. 